\title{
Enhancing the Students' Spirituality Through Ngambri Barokah (Expecting A Blessing) of Kyai in Darul Ulum Islamic Boarding School of Banyuanyar Pamekasan
}

\author{
Zainuddin Syarif ${ }^{1}$, Abdul Gaffar ${ }^{2}$ \\ Post graduate Program of Institut Agama Islam Negeri (IAIN) Madura, Indonesia ${ }^{1}$ \\ Islamic Education Faculty of Tarbiyah, Institut Agama Islam Al-Khairat Pamekasan Madura, \\ Indonesia $^{2}$

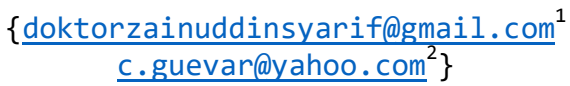

\begin{abstract}
In pesantren or Islamic boarding school, the kyai is very sacred because he is considered having the practice of Hizb believed to be able to bring barakah (blessing) by the majority of santri (students). Barokah (grace), Sawada' (humility), and muru'ah (honor) are the tradition of exoteric teachings in Islamic boarding school in which if the students violate it; it will give them negative impact. i.e., they will get tola (accursed) and bhâsto (karma). The phenomenon of obedience of sam'an wată'atan (obedience and loyal) model by expecting barokah to earn the good fortune of the students' lives both in the world and the hereafter is part of the uniqueness in enhancing the spirituality of santri (students) in Islamic boarding school. All students have a belief in the existence of barakah, karma of kiai as the source of all power that demands them (students) to be submissive, the kiai is believed to be a central figure who does not only have the knowledge of religion (wisdom) but also have supernatural powers which is in Sufism term called as kasyf (unveiling) or 'Irfan.
\end{abstract}

Keywords: Obedience Of Santri, Spirituality, Barakah

\section{Introduction}

Pesantren or Islamic boarding school is educational institution with Islamic religious base that is growing dynamically and got recognition from society in the archipelago, with boarding school model (college), where all residents (the students) receive a good Islamic Teaching either esoterically (Sufi) or exoterically (sharia of fiqh) [1]. The implications of the great value called as the inner capacity of Kiai gives a very big impact, especially to the students' development. For us who have experienced studying in Islamic boarding school must be familiar with the term of "ngambri Barokah kepada sang kyai" or "hope blessing from the Kyai".

All people may have different perception about the concept of blessing, But, that is the uniqueness of the knowledge of the blessing. For santri or the students of Darul Ulum Islamic boarding school, blessing is part of their weapon to get meritorious knowledge. If they do not get it, they will not get happiness in their entire life. The internalization of blessing is considered to be able to increase the students' spirituality, it is proven by all the students' 
effort in vying for the blessing from their kyai. These issues become the focus in this study, i.e. what kind of students' spirituality in Darul Ulum Banyuanyar Islamic boarding school Pamekasan, what kind of factors that influence and motivate them to vie hoping blessing from the kyai.

Darul Ulum Islamic Boarding School of Banyuanyar is geographically located in Poto'an Daja Village, Palengaan District, Pamekasan, Madura. Up to now, the numbers of the students who were studying there were about 6 thousand students. The early establishment of Banyuanyar Islamic Boarding School originated from the anxiety of kyai Ishaq bin Abdurrahman about underdevelopment and stupidity of the society at that time, especially the backwardness and stupidity about Islamic religious knowledge.

\section{Result and discussion}

\subsection{The Spirituality, Blessing, and The Sacred of Students' Obedience}

Taufik Pasiak classifies four things that become part of observable indicators of spirituality and therefore can be defined conceptually and then measured psychometrically which then called as God Experience. Those four things are spiritual experiences, ritual, positive emotions (gratitude, patience, sincere) and the meaning of life [2]. This mini research does not intend to measure the spirituality of the students of Darul Ulum Banyuanyar, but rather to try to describe the form of spirituality of the students, the factors that influence and motivate them to obey the Kyai or the caretaker of Islamic boarding school (khadimul ma'had).

In the early period (1788-1868), this Islamic boarding school is under controlled by kyai Isbat. Since childhood, he was known as the figure who was very wara' (abstinence) (Islamic term that means abstaining from not only forbidden actions but also from the doubtful things) and tawadu' (humility), he is always very close to Allah, based on the story developing in the society, before founding the Islamic boarding school, kyai Isbat initiated by taqarrub (closeness) to Allah by fasting for one years intentioned and addressed to the Islamic boarding school, his family, and his students [3].

In this case, students could also identify the Kyai as an ideal figure that becomes a connector to the educational genealogy of the Islamic scholars of Islamic science in the past Islamic golden age. The process of socialization and interaction happens in Islamic boarding school allows the students to imitate the attitudes and the behavior of Kyai. Kyai is a role model (uswah) of attitudes and behavior of the students [4]. One of the students of Darul ulum Banyuanyar, Masturil Kirom said: "kyai is the heir of the prophets, so if we disrespect and do not dignify him, means that we are indirectly betraying the prophet"(Interviewed on 14 June 2017).

The title of Kyai is a noble title granted by the society to the figure either because of the extent of religious knowledge he has or his sincerity and integrity. The admiration to kyai is considered as the reflection of ethics (moral) signs that the students have beneficial knowledge [4]. As mentioned in Ta'lim al Muta'allim book by Imam al-Jarnuji, stated that there are two requirements for the students to gain beneficial knowledge, the first is respecting for teachers and the second is respecting the book. The respect and the obedience values are not only referred to the Kyai in personal but also to his family. The expression of respect to his sons and his relatives is commonly expressed by calling them as "lora", or "gus" for the sons and call "nyai" or "neng" for the daughters [5].

The sacrality of students' obedience emphasizes on special relationships. For example, the relationship between the students and the teachers. Kyai has the power to give reward and 
punishment to the students [6]. Reward is usually in the form of blessing believed will be received by the students who obey him. The punishment is usually in the form of warning that threatens the students; for instance, students who disobey him will get useless knowledge [7]. That description is in line with a statement by Ahmad Mustofa, one of the students of Darul Ulum. He stated "the basic reference in thinking and acting in this pesantren (Islamic boarding school) is the writing of Kyai Abdul Hamid bin Istbat hanged in interior wall of the mosque, i.e. "there is no happiness and benefit except beneficial knowledge and fear to Allah SWT since those were the only ways that bring us to the happiness in the world and the hereafter"(interview on 14 June 2017).

The form of the interaction of the kyai- the administrators and the students' can be seen in the following:

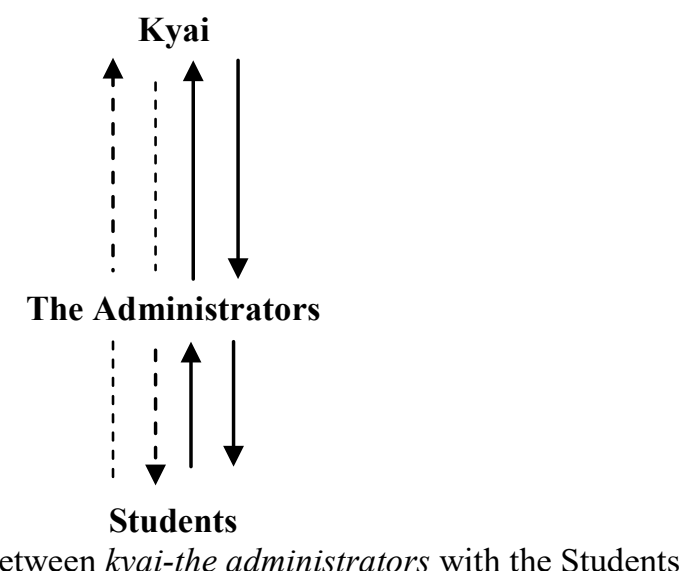

Figure 1. The Interaction between kyai-the administrators with the Students

The students assume that no need trying to determine their own decisions (attitude of independence) because anything has been determined by their authoritative figure [7]. A student stated, "all students are very reluctant and unwillingly to syaikhona (the familiar call of a kyai), everything he commanded is considered as the absolute truth (essential) for students, when kyai is walking in front of the lodge, all students are very ta'dzim (reverence) and kiss his hand, even they are very ta'dzim to the Kyai's pets and plants like: cats, chicken, guava, mango, etc" (interview on 15 June 2017).

The students' obedience can be portrayed that students will receive all his statements without any courage to re-ask, they speak if requested to speak, and execute every command or request kyai, without bravery to reject it. [8] Their willingness is caused by their own desires to gain the good from him. The hope to gain the perceived goodness value is higher than the pursuit of goodness itself [9]. In such conditions, the students have less chance of acquiring the stimulation for new roles that required their own responsibility. Consequently, the students will be difficult to develop their sense of independence [7].

In Darul Ulum Islamic Boarding School, because of the great respect for kyai, sometimes the students consider him as a respectable person more than their own parents. It is caused by the consideration that kyai has great contribution in guiding them and educating them about morality that can not be thought by the society [9]. With that status, Kyai is highly respected, adhered to, and his daily attitudes become a reflection that later turns into their guide and their reference in behaving. The figure of kyai is considered as the person who has an undoubted 
level of taqwa. It results in a presumption that does the good thing to the pious and wara' (self-restraint) people will get a blessing from Allah automatically [4].

One of the alumni of Darul Ulum Islamic boarding school, Abdullah Shomad, told about his experience of getting blessed from his kyai, he told "there are numerous types of alumni that are graduated from Banyuanyar Islamic boarding school, previously, at the era of kyai Abdul Hamid bin Itsbat, there was a student who has job just a dishwasher, if the water in jedding (place for ablution in the mosque) used up, he steadfastly fulfill in, after he graduated, he became the leader of a big Islamic boarding school, even the name of that Islamic boarding school was given by one of the leaders of Banyuanyar boarding school. That Islamic boarding school was now known as Nurul Jadid in Probolinggo. And I guess, there are a lot of other unique stories about the students' experiences who have got blessed." (interview on 17 June 2017).

The nature of spirituality is part of the connectedness with God, the universe, and fellow human being [10]. Theoretically, at a certain level, the obedience can hinder the development of someone's independence, because it charges them to do every orders or request of others. Obedience is a change in someone's attitudes and behaviors to follow any request or command from other people [4].

\subsection{The Students' Spirituality Awareness in Expecting the Blessing}

In the students' point of view, Kyai is very close to "the ocean of Islamic knowledge" either esoterically and exoterically, Kyai is viewed as the figure that has unlimited magical power which is inseparable from the world of Sufism knowledge. In sufism, that term is often called as kashf (unveiling) atau 'irfan, a very high spiritual position. He is considered to have found the real truth, understanding and blending in the love of the divine [3].

Kyai is also considered to have the practice of hizb, a practice that is believed to be capable of bringing the magical power, immunity, and safety, or in Madurese language, it is called as Kejunelan (linuwih power). There is a lot of variety of hizb, i.e Hizb al-Nashr, Hizb al-Bahr, Hizb al-Barr, and etc. Those powers commonly come from Central Java and formulated by some sufi who were believed able to bring in blessing and clairvoyance [3].

Barokah (blessing), tawadu' (humility), and muru'ah (honour), are part of the world of Islamic boarding school that implicates to the meaning of tola (accursed) and bhâsto (something that happens because of the deeds while they are studying there). One of the alumnae of Banyuanyar Islamic boarding school, Ach Supriadi, told that "at that time, there was a student used to thieved coconut belongs to Kyai frequently, almost every day, the number of coconut on the tree always reduced. Soon after, the present leader Kyai Abdul Hamid Baqir who had tense characteristic, prays; "whoever that thieved it, may their seven relatives turn into the tiger. Through investigation, it was found that the thief was Sumaina, and very tragic!, when Sumaina passed away, then her corpse turned into a tiger, that tiger then runs to a cave in Teppul mountain, Pegantenan. Suitable for the Kyai's pray, all of seven relatives of Sumaina have tail at every Friday kliwon."(Interview on 15 Juny 2017).

How great the influence of Kyai's interaction with the students is. The values that develop dominantly lead to the emergence of the sense of the students' spirituality. As a statement from Abdul Bahar: "devote to kyai can be done by two ways, i.e. dhahir (apparent action) or batin (inner action). From dhahir action, the students continually enhance their devotion by respecting him and his big family, while from batin (inner) way, the students always remember to enhance their spirituality by sending Fatiha (tawassul) to the teacher (kyai) whether he had passed away or alive (interview on 15 June 2017). 
The power of the blessing can increase the spiritual awareness of the students of Darul Ulum Islamic boarding school, Banyuanyar Pamekasan. Kyai is regarded as a charismatic religious figure, who is believed to have sanctity and the sacredness [11]. For those reasons, all the behavior of kyai is regarded as a justification of absolute truth in religious-charismatic fascination to affect the students. Thus, the exemplary attitudes of kyai always show and use symbols containing obedience moral values (religion) in order to internalize in building the formula of the spiritual mythological culture of blessing. The students respect him more than their own parents. It is caused by the consideration that kyai has great contribution in guiding them and educating them about morality that cannot be done by the society.

Kuntowijoyo said that kyai is an elite figure of the village who specially deals with religious rituals [12]. He has a position not only as a central figure and role model for his students, but more, he is also obeyed by the wider society. Kyai himself recognized as an Islamic scholar who becomes the heir of the prophets and simultaneously continues the genealogy of the previous Islamic scholars considered as the heir of the greatness of classical Islam [3]. The figure of kyai is deliberated as a figure who has undoubted faith till there is appeared presumption that do the good thing to the pious and wara' (self-restraint) people, will bring in blessing from Allah automatically.

The blessing is an effort to cultivate and to develop the innate potential, either physically and spiritually, based on the values included in Islamic Sufism spirituality. The aim was to create people who have great personality intact as an individual and social being, and also have the spirit of tauhid. That is, the devotion and the sincerity that move dynamically and oriented only to Allah [13]. Tauhid is the starting point of prophet Mohammad's preaching in proclaiming the Islamic teaching to all human.

The blessing is a medium and facilitator between themselves with the supernatural. Therefore, the blessing is viewed as the garden of paradise for the students and the power to get happiness in life. The blessing is a privilege thing. It can be used as "breakfast" of human's spiritual. Therefore, those who are not be blessed, will be unfortunate either in the world or the hereafter. In an attempt to change mindset and perspective of Makkah residents who did not admit the truth of Islam, the basic provision of Prophet Muhammad is only to make tauhid as the only one alternative solution in order that they have the humility to accept the truth of Islam (doctrine of Islamic truth).

\section{Conclusion}

Thus, there are three things that can be inferred by the researcher. The first, students always expect the enlightenment from the kyai. The students who have the obligation seeking knowledge should face many challenges and various problems. Either it related to the urge of lust (private), family, or the neighborhood of the fellow students.

The second, tabarrukan (attaining blessing) or expecting blessing from kyai. The concept of blessing cannot be described, it can only be felt by spiritual experiences. However, based on the definition, the blessing is ziyadah al-khair (improvement of goodness); however, related to this case, the students have other interpretation. For them, by only dignifying kyai in Islamic boarding school means that they already feel tabarrukan or get blessed, moreover if they can meet him face to face and received religious advice.

The third, the longing, the longing and love to kyai and his family as the longing of kyai to his students. The longing, in this case, is for Muhammad pbuh. That was appreciated by students to kyai until wusul (reach and connect) to Allah through acts of devotion that connect each other. 


\section{References}

[1] Asnawir, "The Correlation between Character Building and Peaceful Thinking of Students at Darussalam Islamic Boarding School Ponorogo-East Java," Al-Ta'lim J., vol. 2, no. 19, 2012.

[2] T. Pasiak, Tuhan dalam Otak Manusia: Mewujudkan kesehatan spiritual berdasarkan neurosains. Bandung: Mizan, 2012.

[3] Z. Syarif, Manajemen Pesantren dari Tradisional hingga Modern. Yogyakarta: Sunan: Kalijaga Press, 2006.

[4] D. Rahardjo, Pesantren dan Pembaharuan. Jakarta: LP3ES, 1998.

[5] N. Madjid, Bilik-Bilik Pesantren; Sebuah Potret Perjalanan. Jakarta: Paramadina, 1997.

[6] M. Sirry, "The Public Expression of Traditional Islam: the Pesantren and Civil Society in Post-Suharto Indonesia," Muslim World, vol. 100, no. 1, pp. 60-77, Jan. 2010.

[7] Z. Dhofier, Tradisi Pesantren; Studi tentang Pandangan Hidup Kiai. Jakarta: LP3ES, 1982.

[8] R. A. Lukens-Bull, "The Pesantren Tradition: A Study of the Role of the Kyaiin the Maintenance of the Traditional Ideology of Islam in Java," J. Asian Stud., vol. 4, p. 59, 2002.

[9] J. D. Howell, "Sufism and the Indonesian Islamic Revival," J. Asian Stud., vol. 60, no. 3, p. 701, Aug. 2001.

[10] J. Ujam, Psikologi Transpersonal. Bandung: Pustaka Setia, 2012.

[11] Z. Syarif, "Dinamika Politik Kiai dan Santri dalam Pilkada Pamekasan," IAIN Sunan Ampel, Surabaya, 2011.

[12] Kuntowijoyo, Sosial dalam Masyarakat Agraris Madura 1850-1940. Yogyakarta: Matabangsa, 2002.

[13] A. Mas'ud, Intelektual Pesantren: Perhelatan Agama dan Tradisi. Yogyakarta: LKIS, 2004. 